\title{
DIEL VARIATION OF LARVAL FISH ABUNDANCE IN THE AMAZON AND RIO NEGRO
}

\author{
ARAUJO-LIMA, C. A. R. M., ${ }^{1}$ SILVA, V. V. da, ${ }^{1}$ PETRY, P., ${ }^{1}$ OLIVEIRA, E. C. ${ }^{2}$ and \\ MOURA, S. M. L. ${ }^{2}$ \\ ${ }^{1}$ Inpa, Instituto Nacional de Pesquisas da Amazônia, CPBA, C.P. 478, CEP 69011-970, Manaus, AM, Brazil \\ ${ }^{2}$ ICB, Universidade Federal do Amazonas, CEP 69077-000, Manaus, AM, Brazil \\ Correspondence to: Carlos A. R. M. Araujo-Lima, Inpa, CPBA, C.P. 478, CEP 69011-970, Manaus, AM, \\ Brazil, e-mail: calima@impa.gov.br \\ Received April 13, 2000 - Accepted July 5, 2000 - Distributed August 31, 2001
}

(With 1 figure)

\begin{abstract}
Many streams and large rivers present higher ichthyoplankton densities at night. However, in some rivers this does not occur and larvae are equally abundant during the day. Larval drift diel variation is an important information for planning sampling programs for evaluating larval distribution and production. The aim of this study was to test whether the abundance of larval fish was different at either period. We tested it by comparing day and night densities of characiform, clupeiform and siluriform larvae during five years in the Amazon and one year in Rio Negro. We found that larvae of three species of characiform and larvae of siluriform were equally abundant during day and night in the Amazon. Conversely, the catch of Pellona spp. larvae was significantly higher during the day. In Rio Negro, however, larval abundance was higher during the night. These results imply that day samplings estimate adequately the abundance of these characiform and siluriform larvae in the Amazon, but not Pellona larvae. Evaluations of larved densities of Rio Negro will have to consider night sampling.
\end{abstract}

Key words: Amazon, fish, larvae, river, diel distribution.

\section{RESUMO}

\section{Variação nictimeral na deriva de larvas no Rio Amazonas}

Em muitos riachos e rios o ictioplâncton é mais abundante à noite do que de dia. Entretanto, em alguns rios isto não acontece e as larvas são igualmente abundantes durante o dia. Essa informação é importante para avaliar a distribuição e a produção de larvas nos rios. O objetivo deste trabalho foi testar se ocorrem diferenças na deriva larval durante os dois períodos do dia no Rio Solimões/Amazonas e no Rio Negro. Testamos esta hipótese comparando as densidades diurna e noturna em larvas de characiformes, clupeiformes e siluriformes durante cinco anos no Rio Solimões/Amazonas e um ano no Rio Negro. Encontramos que as larvas de três espécies de Characiformes e as larvas de Siluriformes de fato não modulavam sua deriva sendo igualmente abundantes durante o dia e à noite. Ao contrário, as larvas de Pellona spp. eram mais abundantes durante o dia. No Rio Negro as larvas eram mais abundantes à noite. Este resultado tem importantes implicações para o planejamento de amostragem de larvas no Rio Solimões/Amazonas, pois indica que coletas diurnas estimam adequadamente a deriva de larvas de algumas espécies de characiformes e siluriformes no Rio Solimões/Amazonas, mas não das larvas de clupeiformes e das larvas do Rio Negro.

Palavras-chave: Amazônia, peixe, larva, distribuição nictimeral.

\section{INTRODUCTION}

Studies on larval fish abundance allow important inferences about the spawning grounds, reproductive season and migration pattern of fishes
(Goulding, 1980; Pavlov, 1994). Larval densities can also be used to estimate abundance index that when correlated to fisheries yield provides an alternative approach for measuring the size of the spawning stock (Smith \& Richardson, 1977). 
Appropriate measurements of larval density depend on the drift pattern of larval fish. Downstream migration of riverine larvae has been found to be more intense during the night in many streams and large rivers, such as Volga, Paraná, Columbia and Missouri (Kindschi et al., 1979; Graser, 1979; Gale \& Mohr, 1978; Hergenrader et al., 1982; Nezdoliy, 1984; Naesje et al., 1986; Corbett \& Powles, 1986; Gehrke, 1992; Baumgartner, 1995; Gadomski \& Barfoot, 1998). In other rivers, such as Ili, Kuban, Mississipi and Mekong, however, daytime drift was equally intense (Pavlov et al., 1977; Holland, 1986; De Graaf et al., 1999). The drift modulation has been explained mostly by larval vision. During daylight larvae can see and therefore, avoid the net (Matsuura, 1977) and/or receive visual clues sufficient for it to orientate and swim towards the shore (Arnold, 1974; Gadomski \& Barfoot, 1998).

Many migratory fishes of the Amazon basin, including those exploited by fisheries, are open water spawners (Balon, 1975). They spawn in the Amazon River and its tributaries, where larvae drift for a few days before being carried into the floodplains (Petry, 1989; Araujo-Lima \& Oliveira, 1998). Spawning season occurs during the flood. In this report we compare the day and night abundance of drifting larval fish in the Amazon River during five years and Rio Negro during one year. It was our aim to know if there were any differences between day and night catches. This information is important to help designing future larval surveys in Amazonian rivers.

\section{MATERIAL AND METHODS}

There were six and five sampling stations in the Amazon and Rio Negro, respectively (Fig. 1). They were located in sites 3 to $10 \mathrm{~m}$ deep at 10 to $25 \mathrm{~m}$ off banks. We sampled the larvae with a bongo net $\left(0.43 \mathrm{~m}^{2}\right.$ diameter $\times 2 \mathrm{~m}$ long) equipped with a General Oceanics flowmeter during the spawning seasons 1986-1987, 1996-1997 and 1999-2000. The net was towed for 15 minutes $\left(\sim 1 \mathrm{~m} . \mathrm{s}^{-1}\right)$ at the side of the boat, against the current, 1 to 2 meters deep. Sample volume varied from 10 to $50 \mathrm{~m}^{3}$. The Amazon's sampling stations were chosen because of their high larval densities, as shown by previous studies (Oliveira \& Araujo-Lima, 1998; Araujo-Lima \& Oliveira, 1998). The stations of Costa do Catalão (station 1) and Boca do Lago do Rei (station 2) were sampled in four and five dates, respectively, and the other stations were sampled only once, totalling 13 paired replicates (Table 1). Paired replicates in Rio Negro summed 10, and the stations 7,8 and 9 were sampled at least twice (Table 2). Day sampling was between 8:0017:00 $\mathrm{h}$ and night sampling between 20:00 and 4:00 $\mathrm{h}$. The exact sampling time was randomly chosen in a 24:00 h cycle, excluding dawn and dusk.

We sorted out the larvae of two species of Serrasalmidae (Mylossoma duriventre Cuvier, 1817 and M. aureum Spix, 1829), one species of Characidae (Triportheus elongatus Gunther, 1864), one species of Tetraodontidae (Colomesus asellus Muller \& Trochel, 1848), one genus of Clupeidae (Pellona spp. Valenciennes, 1847) and total siluriform in Amazon samples. Total characiform larvae was also estimated. Rio Negro samples were sorted only by order or family because its species cannot be identified yet. After calculating the larval densities (larvae. $\mathrm{m}^{-3}$ ), we compared day and night catches with paired t tests.

\section{RESULTS}

Larval densities of siluriforms, $M$. duriventre, M. aureum, T. elongatus and total characiforms larvae were not significantly different in day and night catches (Table 1). The paired t tests of the latter two species excluded the ties. Day catches of Pellona spp. were, however, significantly higher than night catches (paired t test; $\mathrm{t}=3.03$; d.f. $=12$; $p=0.01$ ). The mean day to night ratio was $4: 1$. The data for $C$. asellus included an excessive number of ties, therefore no statistical analysis could be completed, but larval densities did not show any tendencies to be higher at day or night catches.

The densities of total characiform and clupeiform larvae in Rio Negro were significantly higher at night (paired t test for clupeiforms; $\mathrm{t}=2.4$; d.f. $=$ $9 ; \mathrm{p}=0.04$; paired $\mathrm{t}$ test for characiforms; $\mathrm{t}=2.83$; d.f. $=9 ; p=0.02$ ) (Table 2). The mean day to night ratio was 1:4 in characiforms and 1:9 in clupeiforms. We could not sample enough larvae of Plagioscion to do a conclusive statistical analysis, but the values found in seven positive samples suggested this genus was also more abundant at night in Rio Negro.

\section{DISCUSSION}

Larval abundance showed different diel patterns in the two rivers. Characiform and siluriform larvae were equally abundant in the Amazon stream during the day and the night. Pellona spp. larvae did not fit in this trend, being more abundant during the daytime. Conversely, in Rio Negro these same larval groups were more abundant at night. 


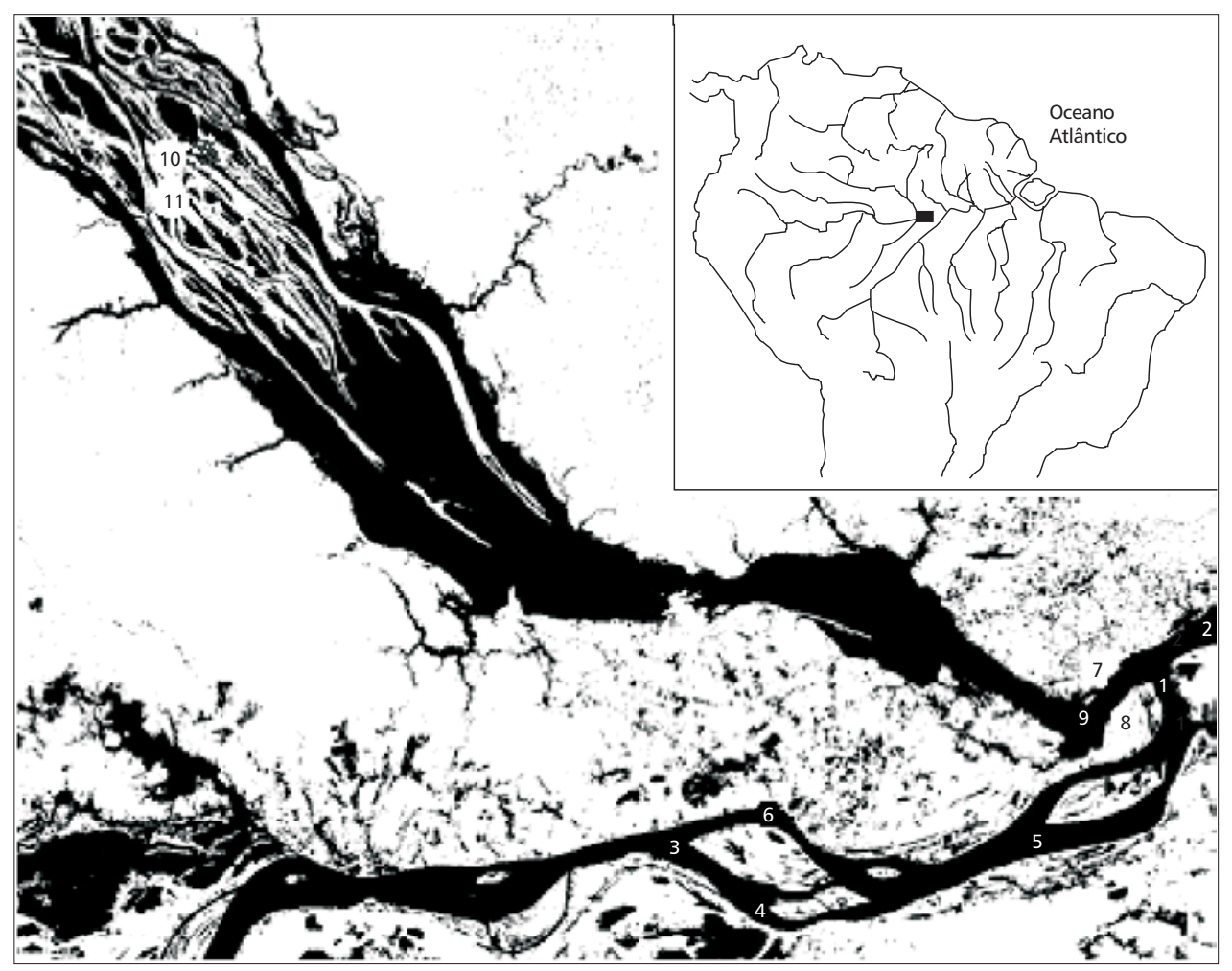

Fig. 1 - Studied area and the sampling stations. Sampling stations 1 to 6 are in the Amazon and 7 to 11 in Rio Negro.

TABLE 1

Larval densities (larvae.m ${ }^{-3}$ ) of Pellona spp., total Siluriformes, total and three species of Characiformes at day night in six sampling stations of the Amazon and the statistics of paired t tests. Stations locations are presented in Fig. 1.

\begin{tabular}{|c|c|c|c|c|c|c|c|}
\hline \multirow{3}{*}{ Station } & \multirow{3}{*}{ Date } & \multicolumn{2}{|c|}{ Siluriformes } & \multicolumn{2}{|c|}{ Clupeiformes } & \multicolumn{2}{|c|}{ Characiformes } \\
\hline & & \multicolumn{2}{|c|}{ spp. } & \multicolumn{2}{|c|}{ Pellona spp. } & \multicolumn{2}{|c|}{ spp. } \\
\hline & & Day & Night & Day & Night & Day & Night \\
\hline 1 & $18 / 12 / 1996$ & 3.33 & 0.44 & 7.33 & 1.06 & 6.00 & 3.45 \\
\hline 1 & $05 / 02 / 1997$ & 0.10 & 0.20 & 9.00 & 1.52 & 10.20 & 21.01 \\
\hline 1 & $06 / 03 / 1997$ & 2.00 & 2.98 & 3.81 & 0.29 & 106.29 & 123.94 \\
\hline 1 & $20 / 03 / 1997$ & 1.25 & 5.66 & 5.94 & 0.91 & 50.42 & 63.43 \\
\hline 2 & $04 / 12 / 1986$ & 0.28 & 0.42 & 0 & 0 & 10.99 & 8.19 \\
\hline 2 & $21 / 01 / 1987$ & 0.19 & 0.17 & 1.39 & 0.67 & 65.49 & 17.73 \\
\hline 2 & $31 / 01 / 1987$ & 0.85 & 0.80 & 0.59 & 0 & 33.55 & 34.00 \\
\hline 2 & $18 / 02 / 1987$ & 0.65 & 0.84 & 0 & 0 & 65.95 & 6.75 \\
\hline 2 & $18 / 03 / 1987$ & 0.32 & 0.72 & 0 & 0 & 0.43 & 0.90 \\
\hline 3 & 04/03/1997 & 0.42 & 0.60 & 0.02 & 0.56 & 1.93 & 10.52 \\
\hline 4 & 19/03/1997 & 2.22 & 3.32 & 1.79 & 0.10 & 32.57 & 22.75 \\
\hline 5 & $19 / 03 / 1997$ & 12.66 & 5.00 & 0.68 & 0.18 & 71.92 & 31.41 \\
\hline 6 & $27 / 01 / 2000$ & 0.05 & 0 & 5.50 & 0.83 & 7.56 & 5.39 \\
\hline $\mathrm{t}$ & & & & & & & \\
\hline d.f. & & & & & & & \\
\hline $\mathrm{p}$ & & & & & & & \\
\hline
\end{tabular}


TABLE 1 (continued)

\begin{tabular}{|c|c|c|c|c|c|c|c|}
\hline \multirow{3}{*}{ Station } & \multirow{3}{*}{ Date } & \multicolumn{6}{|c|}{ Characiformes } \\
\hline & & \multicolumn{2}{|c|}{ T. elongatus } & \multicolumn{2}{|c|}{ M. duriventre } & \multicolumn{2}{|c|}{ M. aureum } \\
\hline & & Day & Night & Day & Night & Day & Night \\
\hline 1 & $18 / 12 / 1996$ & 0 & 0.13 & 0 & 0.27 & 1.33 & 1.73 \\
\hline 1 & 05/02/1997 & 0.52 & 2.12 & 0.30 & 7.27 & 0 & 5.25 \\
\hline 1 & 06/03/1997 & 2.19 & 19.62 & 5.05 & 24.33 & 3.71 & 6.06 \\
\hline 1 & $20 / 03 / 1997$ & 0.52 & 6.67 & 6.25 & 21.41 & 0.73 & 2.42 \\
\hline 2 & $04 / 12 / 1986$ & 0 & 0 & 1.41 & 0 & 0 & 0 \\
\hline 2 & $21 / 01 / 1987$ & 3.34 & 0.08 & 2.69 & 0.59 & 0.93 & 0.25 \\
\hline 2 & $31 / 01 / 1987$ & 0.07 & 0 & 2.15 & 0 & 0 & 0 \\
\hline 2 & $18 / 02 / 1987$ & 1.29 & 0.08 & 4.96 & 0.17 & 0.65 & 0 \\
\hline 2 & $18 / 03 / 1987$ & 0 & 0.12 & 0.01 & 0 & 0 & 0 \\
\hline 3 & 04/03/1997 & 0 & 0.67 & 0 & 1.59 & 0 & 0.12 \\
\hline 4 & $19 / 03 / 1997$ & 0.98 & 2.24 & 3.17 & 5.05 & 0.05 & 0.07 \\
\hline 5 & $19 / 03 / 1997$ & 1.66 & 1.20 & 11.16 & 6.00 & 0.29 & 0.16 \\
\hline 6 & $27 / 01 / 2000$ & 0.67 & 0.83 & 0.86 & 1.66 & 0.19 & 0.21 \\
\hline & \multicolumn{2}{|c|}{1.21} & \multicolumn{2}{|c|}{1.16} & \multicolumn{2}{|c|}{1.48} \\
\hline \multicolumn{2}{|l|}{ d.f. } & \multicolumn{2}{|c|}{11} & \multicolumn{2}{|c|}{11} & \multicolumn{2}{|c|}{10} \\
\hline \multicolumn{2}{|l|}{$\mathrm{p}$} & \multicolumn{2}{|c|}{0.250} & \multicolumn{2}{|c|}{0.270} & \multicolumn{2}{|c|}{0.171} \\
\hline
\end{tabular}

TABLE 2

Larval densities (larvae. ${ }^{-3}$ ) of Plagioscion spp., total Clupeiformes and Characiformes at day and night in five sampling stations of Rio Negro and the statistics of paired tests. Station locations are presented in Fig. 1.

\begin{tabular}{|c|c|c|c|c|c|c|c|}
\hline \multirow[t]{2}{*}{ Station } & \multirow[t]{2}{*}{ Date } & \multicolumn{2}{|c|}{$\begin{array}{c}\text { Scionidae plagioscion } \\
\text { spp. }\end{array}$} & \multicolumn{2}{|c|}{$\begin{array}{l}\text { Clupeiformes } \\
\text { spp. }\end{array}$} & \multicolumn{2}{|c|}{$\begin{array}{c}\text { Characiformes } \\
\text { spp. }\end{array}$} \\
\hline & & Day & Night & Day & Night & Day & Night \\
\hline 7 & $13 / 12 / 1999$ & 0 & 0.08 & 0.25 & 0.65 & 0.19 & 1.20 \\
\hline 7 & $14 / 12 / 1999$ & 0 & 0 & 0 & 0.07 & 0.05 & 0.34 \\
\hline 7 & $21 / 12 / 1999$ & 0 & 0.10 & 0 & 0.20 & 0.03 & 0.15 \\
\hline 8 & $21 / 12 / 1999$ & 0 & 0.46 & 0.21 & 0.84 & 0 & 1.26 \\
\hline 8 & $21 / 12 / 1999$ & 0 & 0 & 0 & 6.69 & 0 & 2.69 \\
\hline 8 & $17 / 01 / 2000$ & 0 & 0.09 & 3.35 & 9.80 & 0.95 & 1.03 \\
\hline 9 & $17 / 01 / 2000$ & 0 & 0 & 0.23 & 1.43 & 0.93 & 1.98 \\
\hline 9 & $17 / 01 / 2000$ & 0 & 0.03 & 0 & 0.05 & 0.22 & 0.23 \\
\hline 10 & $02 / 12 / 1999$ & 0 & 0.95 & 0 & 14.78 & 0.04 & 0.32 \\
\hline 11 & $02 / 12 / 1999$ & 0 & 0.07 & 0 & 6.72 & 0 & 0.54 \\
\hline \multicolumn{2}{|l|}{$\mathrm{t}$} & \multicolumn{2}{|c|}{1.84} & \multicolumn{2}{|c|}{2.40} & \multicolumn{2}{|c|}{2.83} \\
\hline \multicolumn{2}{|l|}{ d.f. } & \multicolumn{2}{|c|}{9} & \multicolumn{2}{|c|}{9} & \multicolumn{2}{|c|}{9} \\
\hline \multicolumn{2}{|l|}{$\mathrm{p}$} & \multicolumn{2}{|c|}{0.1} & \multicolumn{2}{|c|}{0.04} & \multicolumn{2}{|c|}{0.02} \\
\hline
\end{tabular}


Possible explanations for the differences between day/night catches in the two rivers might be related to larval vision. Vision could affect larval densities in at least two ways, which are additive. First, if the larvae could see the net they could try to avoid it, resulting in lower catches (Matsuura, 1977; Gadomsky \& Barfoot, 1998). Second, if the larvae could see particles drifting in the river, such as sediments and detritus, they could orientate themselves and control their drift in the river (Arnold, 1974; Pavlov, 1994), which would also be reflected by the catches.

Vision, would affect day/night catches ratios differently in the two rivers. The transparency of the Amazon River near Manaus during the flood season is less than $30 \mathrm{~cm}$ (Secchi depth) (Fisher, 1978; Forsberg et al., 1988; Engle \& Melack, 1993) and of Rio Negro is approximately $2 \mathrm{~m}$ (Rai \& Hill, 1984). The low transparency of the Amazon would not interfere on net avoidance during the day. In Rio Negro, the transparency is higher and the larvae would be able to see the net during the day, but not during the night.

The loss of orientation by the larvae could also explain catch differences. Larvae near the surface of the water column would not be able to see the bottom to orientate themselves, but if there were particles being carried along with the current, they might be able to receive visual clues sufficient for it to orientate to the apparent direction of the flow (Arnold, 1974). Pavlov and collaborators, who studied the ichthyoplankton of large Asian rivers (Pavlov et al., 1977; Pavlov, 1994) attributed the day/night drift differences to the loss of visual orientation of larvae in turbid waters. They postulated that when transparency is lower than $30 \mathrm{~cm}$ the larvae are not able to orientate themselves and dowstream displacement would be continuous. The effect of the loss of orientation would also lead to high larval densities in Rio Negro during the night and similar densities during day and night in the Amazon.

An additional explanation for the pattern of larval drift not related to vision would be larval behaviour. Some authors suggested that the beginning of downstream displacement was not passive (Nezdoliy, 1984; Naesje et al., 1986; Corbett \& Powles, 1986). When the moment is appropriate the larvae actively leave the shoreline moving towards the stream. This movement seems to be influenced by abiotic factors, such as illumination, and the selection of drift during the night has been considered to be an anti-predator adaptation (Blaxter, 1986; Pavlov, 1994).

Night drift would offer limited protection against predation in the Amazon. Firstly, because light penetration during the day is very low. Secondly, because predators of larvae in the Amazon include gymnotids and catfishes (Moura, 1998), which do not rely on vision to find their prey, using electrolocation and chemoreception instead. So only the predation pressure exerted by the characiform and clupeid larvae would depend on light penetration. There is no information about predators of larvae for Rio Negro, but probably they are similar to those found in the Amazon.

In some studies diel differences in larval densities were related to vertical migration (Kindschi, 1979; Nezdoliy, 1984). In the Amazon this is irrelevant, but in Rio Negro diel changes may be caused by nocturnal migration to surface and should be subject of future studies. The drift of Pellona in the Amazon, however, may result from other forces. Some studies on larval distribution of clupeiforms reported higher larval density during the day, so it seems to be a pattern of this group in freshwater (Graser, 1979; Gadomski \& Barfoot, 1998). The advantage of this trend is not clear and may be related to larval vision or its predation strategy.

Our findings have some implications for future larval surveys. The lack of strong differences in densities of the three species characiforms and of siluriform larvae suggests that either day or night sampling in the Amazon will provide equally good estimations of their larval abundance.

Day sampling is normally chosen because of its convenience. However, the drift modulation of Pellona larvae, implies that other species, possibly including other characiform species, may show distinct migration patterns, and it is not possible to extrapolate the results for the whole larval community of the Amazon River. Larval sampling in Rio Negro should be done during both day and night periods.

Acknowledgments - Project funded by Inpa/CNPq, PPI 3090. We acknowledge the field assistance of José Fernandes Alves, Antonio Adalberto Silva, Agenor Negrão, Luis Cosmo and Valter Dias. 


\section{REFERENCES}

ARAUJO-LIMA, C. A. R. M. \& OLIVEIRA, E. C., 1998, Transport of larval fish in the Amazon. Journal of Fish Biology, 53: 297-306.

ARNOLD, G. P., 1974, Rheotropism in fishes. Biological Review, 49: 515-576.

BALON, E. K., 1975, Reproductive guilds of fishes. A proposal and definition. Journal of Fisheries Research Board of Canada, 32: 821-864.

BAUMGARTNER, M. S. T., 1995, Utilização de ambientes da planície de inundação do alto Rio Paraná para o desenvolvimento de larvas de curvina, Plagioscion squamosissimus (Heckel, 1840) (Perciformes, Scianidae). Dissertação de Mestrado, Universidade Estadual de Maringá, Maringá, 28p.

BLAXTER, J. H. S., 1986, Development of sense organs and behavior of teleosts larvae with special reference to feeding and predator avoidance. Transactions of the American Fisheries Society, 115: 98-114.

CORBETT, B. W. \& POWLES, P. M., 1986, Spawning and larva drift of sympatric walleyes and white suckers in an Ontario Stream. Transactions of the American Fisheries Society, 115: 41-46.

DE GRAAF, G. J., BORN, A. F., UDDIN, A. M. K. \& HUDA, S., 1999, Larval fish movement in the river Lohajang, Tangail, Bangladesh. Fisheries Management and Ecology, 6: 109-120.

ENGLE, D. L. \& MELACK, J. M., 1993, Consequences of riverine flooding for seston and the periphyton of floating meadows in an Amazon floodplain lake. Limnology and Oceanography, 38: 1500-1520.

FISHER, T. R., 1978, Plâncton e produção primária em sistemas aquáticos da bacia da Amazônia Central. Acta Amazonica, 8 (supl.): 43-54.

FORSBERG, B. R., DEVOL, A. H., RICHEY, J. E., MARTINELLI, L. A. \& SANTOS, H., 1988, Factors controlling nutrient concentrations in Amazon floodplain lakes. Limnology and Oceanography, 33: 41-56.

GADOMSKI, D. M. \& BARFOOT, C. A., 1998, Diel and distributional abundance patterns of fish embryos and larvae in the lower Columbia and Deschutes rivers. Environmental Biology of fishes, 51: 353-368.

GALE, W. F. \& MOHR, J., 1978, Larval fish drift in a large river with a comparison of sampling methods. Transactions of the American Fisheries Society, 107: 46-55.

GEHRKE, P. C., 1992, Diel abundance, migration and feeding of fish larvae (Eleotridae) in a floodplain billabong. Journal of Fish Biology, 40: 695-708.

GOULDING, M., 1980, The fishes and the forest: Explorations in Amazonian natural history. University of California Press, Los Angeles, 200p.

GRASER, L. F., 1979, Spatio-temporal distribution of clupeid larvae in Barkley reservoir. In: R. D. Hoyt (ed.), Proceedings of Third Symposium on Larval Fish. Western Kentucky University, Bowling Green.
HERGENRADER, G. L., HARROW, L. G., KING, R. G., CADA, G. F. \& SCHLESINGER, A. B., 1982, Larval Fishes in the Missouri River and the Effects of Entrainment. In: L. W. Hesse (ed.), The Middle Missouri River. The Missouri River Study Group, Norfolk.

HOLLAND, L. E., 1986. Distribution of early life history stages of fishes in selected pools of the upper Mississipi river. Hydrobiologia, 136: 121-130.

KINDSCHI, G. A., HOYT, R. D. \& OVERMANN, G. J., 1979, Some aspects of the ecology of larval fishes in Rough River lake, Kentucky. In: R. D. Hoyt (ed.), Proceedings of Third Symposium on Larval Fish. Western Kentucky University, Bowling Green.

MATSUURA, Y., 1977, A study of the undersampling problem of fish larvae observed at the fixed stations in south Brazil. Boletim do Instituto Oceanográfico, São Paulo, 26: 273-283.

MOURA, S. M. L., 1998, Predação de larvas de peixes no Rio Amazonas. Dissertação de Mestrado, Inpa/UA, Manaus, 29p.

NAESJE, T. F., JONSSON, B. \& SANDLUND, O. T., 1986, Drift of Cisco and Whitefish in a Norwegian River. Transactions of the American Fisheries Society, 115: 89-93.

NEZDOLIY, V. K., 1984, Downstream migration of young fishes during the initial period of flow regula-tion of the Ili River. Journal of Ichthyology, 24: 34-46.

OLIVEIRA, E. C. \& ARAUJO-LiMA, C. A. R. M., 1998, Distribuição espacial das larvas de Mylossoma aureum e $M$. duriventre (Pisces; Serrasalmidae) nas margens do rio Solimões, AM. Rev. Brasil. Biol., 58: 349-358.

PAVLOV, D. S., 1994, The downstream migration of young fishes in rivers: mechanisms and distribution. Folia Zoologica, 43: 193-208.

PAVLOV, D. S., PAKHORUKOV, A. M., KURAGINA, G. N., NEZDOLIY, V. K., NEKRASOVA, N. P., BRODSKIY, D. A. \& ERSLER, A. L., 1977, Some features of downstream migrations of juvenile fishes in the Volga and Kuban Rivers. Journal of Ichthyology, 19: $363-374$.

PETRY, P., 1989, Deriva de ictioplâncton no Paranã do Rei, várzea do Careiro, Amazônia Central, Brasil. Dissertação de Mestrado, Inpa/FUA, Manaus, 68p.

RAI, H. \& HILL, G., 1984, Primary production in the Amazonian aquatic ecosystem. In: H. Sioli (ed.), The Amazon. Limnology and landscape ecology of a mighthy river and its basin. Dr. W. Junk Publishers, Dordrecht.

SMITH, P. E. \& RICHARDSON, S. L., 1977, Standard techniques for pelagic fish egg and larva surveys. FAO Fisheries Technical Paper, 175: 100p. 